Please do not remove this page

RMIT

UNIVERSITY

\title{
Devising a quality management system for new service-support contracts in industry
}

McLay, Allan; Everett, Robert; Keith-Storey, Andrew

https://researchrepository.rmit.edu.au/esploro/outputs/9921860314901341/filesAndLinks?institution=61RMIT_INST\&index=null

McLay, A., Everett, R., \& Keith-Storey, A. (2016). Devising a quality management system for new service-support contracts in industry. International Journal of Agile Systems and Management, 9(4), 340-362. https://doi.org/10.1504/IJASM.2016.10002501

Document Version: Accepted Manuscript

Published Version: https://doi.org/10.1504/IJASM.2016.10002501

Repository homepage: https://researchrepository.rmit.edu.au

Copyright (c) 2016 Inderscience Enterprises Ltd.

Downloaded On 2023/04/26 12:40:44 +1000 
Thank you for downloading this document from the RMIT Research Repository.

The RMIT Research Repository is an open access database showcasing the research outputs of RMIT University researchers.

RMIT Research Repository: http://researchbank.rmit.edu.aul

\begin{abstract}
Citation:
McLay, A, Everett, R and Keith-Storey, A 2016, 'Devising a quality management system for new service-support contracts in industry', International Journal of Agile Systems and Management, vol. 9, no. 4, pp. 340-362.
\end{abstract}

See this record in the RMIT Research Repository at:

https://researchbank.rmit.edu.au/view/rmit:39606

Version: Accepted Manuscript

Copyright Statement:

(C) 2016 Inderscience Enterprises Ltd.

Link to Published Version:

https://dx.doi.org/10.1504/IJASM.2016.10002501 


\title{
Devising a Quality Management System for new service-support contracts in industry
}

\begin{abstract}
This study proposes a model for a Quality Management System (QMS) for newly awarded service-support contracts. Data collected from service-support projects within the legal and Defence services sectors is analysed and demonstrates that five key constructs are required when devising an effective QMS for a service-support project. It is proposed that from the outset and throughout a project's life, the contractor can continually use key elements identified within the proposed QMS structure to provide the customer with their anticipated level of service and support whilst delivering an equitable return on investment for customers, contractor management, and associated stakeholders. The model can also be used as an organisational learning instrument and strategy lens to highlight potentials for significant improvements in the performance of service-support systems and to support the establishment and success of future projects.
\end{abstract}

Keywords: Cost of Quality; Customer focus; Leadership; Quality Management System; Service Support.

\section{Introduction}

Quality Management Systems (QMS) form part of an overall organisational architecture that ensures provision of products and services in an efficient and effective manner. In turn, project-based QMSs must be compliant with the organisation's overall approach to quality management and meet the specific requirements of both existing and newly awarded project-based contracts. Thus it is likely that a project focussed organisation will be sustaining multiple QMSs active within the organisation at any one time. This situation presents an opportunity to explore whether or not an agile QMS model could be devised for establishment of a new project QMS upon award of a new contract. This research addressed results of personal interviews (derived from a project within the legal sector) and historical data (from completed projects within the defence industry) to develops a generic QMS framework approach for project-based contracts.

\section{Quality management systems in the literature}

Quality systems elements

Critical organisational elements relevant to Quality Management are widely addressed throughout the literature and collectively provide the requirements for the development of a project QMS. Quality systems have set elements critical to the integration and application of quality management practice to ensure successful delivery of products and services deemed valuable to the customer (Fuentes-Fuentes, Montes \& Fernandez, 2006; Sadikoglu \& Zehir, 2010). Common quality elements identified in the literature are summarised in Table 1. Linked to these elements are endogenous constructs such as benchmarking, statistical control and employee empowered continuous improvement (Ahire, Golhar \& Waller, 1996), along with quality models and standards. The Australian Business Excellence Framework (ABEF) (SAI Global, 2011), European Foundation for Quality Management (EFQM, 2012), ISO10014-2007, ISO9001:2008, ISO9004:2011 and ISO 10006-2003 are such examples. 
Leadership and cost of quality

Propositions in literature have developed models to identify methods in which quality management can be implemented into organisations based on the foundations of organisational management. The role of top management and the impetus of teamwork through workforce participation are critical to the success of implementing and maintaining a QMS (Ab Wahid \& Corner, 2009). Ahire and Ravichandran (2001) posit a diffusion model type 'adoption, adaptation, acceptance and use' (2001, p.448) entailing critical stages such as: declaring commitment, changing attitudes, and changes in behaviours, which become a medium for improved products and services. The diffusion model encompasses key stakeholder needs as a driving force for quality systems implementation. Similar to the ABEF, management leadership, meeting customer needs, product quality, process quality and continuous quality improvement are core business focussed commitments. However, the phraseology used when performing quality leadership enquiries is construed towards having leaders choose which is more important: quality, cost, or schedule. This may be converse to management thinking as each of the concepts may be classed as equally important in a productive business enterprise. The Juran notion of cost of quality (Juran \& Blanton Godfrey, 1999) compels dissemination in terms of economic value to enable top management to embrace the value of quality management practice.

Designing a QMS may also define how the cost of quality is perceived. Cost of Quality models as proposed by Juran and Blanton Godfrey (1999) and Weheba and Elshennawy (2004) do not indicate projected benefits in terms of growth, or external factors such as Taguchi's quality loss imparted on society (Zokaei, Seddon \& Donovan, 2011) and there is an absence of value, opportunity or productivity concepts. Cost may be reworded to voluntary expenditure (quality as an investment), noting that involuntary expenditure is related to cost of poor quality such as rework (Rosenfeld, 2009). Although net savings is embedded in declaring elements such as reduction in rework, there is no indication towards elements such as return on investment or growth opportunity which would provide financial justification for investing in quality.

\section{Benchmarking}

Important factors in the development of a quality system are business dynamics and the contingent perspectives of influential domains such as changing contractual requirements, governance and organisational capabilities. This is in line with Neergaard's (2002) declaration that contingent factors including organisational size, length of company existence, drive for certification and competition, all define the configuration of a quality system although no one design applies to all. In order to determine the type of quality system required, an analysis of the surrounding competitive market needs to be conducted. Green \& Weaver (2006) have discussed utilising a benchmarking model based upon Mentzer, Kahn, and Bienstock, including 'functional integration, approach, systems and performance measurement' (2006, p.4). This approach highlights an association between benchmarking and forecasting external environmental changes, such as changes in customer satisfaction and needs as well as economic dynamics. However, in order to begin the benchmarking process, an analysis of internal collaboration needs to be established (that is, functional integration) as each internal department within an organisation may have its own driving forces and benchmarking criteria. This may require significant leadership dexterity and would be advantageous if performed early in the process. It may be classed as breaking-down the silos (Ensor, 1988) which would be required for transition to a consensus of measurement variables (approach) and then performing and verifying the actual measurements (systems and performance measurement).

Quality system as a product

Bobrek and Sokovic (2005) have compared the QMS design activity to product design process. This is in terms of required outcomes that a product must generate. In the case of a product, the outcomes will be defined by customer need, such as designing a product to perform a required function. A QMS is required to produce certain intangible aspects such as driving towards 
'continuous improvement, customer focus and aligned futuristic and multi-functional' outcomes (Gill, 2009, p. 532). In comparison with Bobrek and Sokovic (2005), Wu, Kay, Looks, and Bennet (2000) also discuss the creation of manufacturing systems management in terms of a four step model which includes business process analysis, evaluation, design and implementation. Van Harten, Casparie and Fisscher (2002) state that developing a QMS is similar to introducing new technology, as a QMS may be considered a 'management technology'.

\section{Industrial requirements}

Contractual statement of work documents are used to establish a project's deliverables. Thus, the performance of an awarded contract needs to be monitored with customer needs constantly re-enforced. Customer expectations can be further translated into an organisation through governing mandates such as ethical behaviours, accurate accountancy, an established quality system, and a positive management approach that can further empower the organisation. McPhee (2009) highlights the importance of transparency, accessibility and responsiveness (further quality dimensions) which augments legitimacy and credibility. These dimensions correlate with the Organisation for Economic Co-operation and Development (OECD) declaration of governance as contributing to economic efficiency and investor confidence (OECD , 2004). The role of the quality system via quality assurance enables a contract to be assessed for efficiency and effectiveness (ANAO, 2012). AS8000:2003 outlines operational and maintenance elements of good governance, these include the establishment of procedures to declare governing requirements, handling of breaches and complaints, record keeping, training, monitoring, review and liaison. These elements may be associated with the clauses within ISO9001 and ISO9004 such as strategy and policy, actions via monitoring and measurement, records, human resource training, management review and customer communication.

Although 'Quality' is defined throughout the literature as a generic philosophy (such as expressed by Juran, Deming, Taguchi) the contingent perspective as discussed by Neergaard (2002) highlights that there may be no singular model to represent the configuration of a QMS. This may be applicable to service type contracts in the defence industry and provides an opportunity to explore and conduct research to determine whether it is possible to devise a QMS that is effectively applicable to a newly awarded contract in the service/project industry.

\section{Ontological perspective of a QMS model}

An approach for developing design ontology for a proposed project QMS is outlined in the following Figure 1. This shows the elements that may be required to devise a QMS for a series of contracts based upon the following suppositions: (a) The drive to becoming adaptable, flexible and innovative on a project is due to customer satisfaction ratings rather than an internal humanistic compulsion for continuous improvement; (b) Customer quality performance measures are not initiated during the start-up of a project as feedback on quality performance is not a primary monitored factor; (c) The people that are capable of planning and have foresight to strive for success are underutilised for expertise on new projects; (d) The focus on investing in the quality of process and product as an outcome provider is not an initial driver; (e) The focus is firstly toward on-time scheduled deliveries and meeting financial income; (f) Collaboration with immediate external stakeholder may exist; (g) Drawing upon customer perceptions of performance with external stakeholders is not taken advantage of.

These suppositions encompass customer, humanistic, performance measurement, planning, outcome focus, and stakeholder quality constructs. To aid quality practitioners in developing quality systems for newly awarded contracts, two aspects of the study require focus: elements that are to be designed into a QMS as described in Figure 1, and service type contracts that have a repetitive structure. Factors to be analysed include: the utilisation of quality methods in order to sustain the success of the organisation; identifying the degree to which industry standards may 
be used in the development of a quality management system; contract obligations (documented customer requirements), organisational capabilities and organisational governance.

(Figure 1)

Figure 1 outlines the elements that contribute to the design of a QMS. The model proposes that upon realisation of market opportunities or an award of a new contract, imperatives such as organisational capabilities, customer requirements and industry responsibilities (such as standards, statutes and regulations) are the foundations for delivery of a product or service. The imperatives are required, in conjunction with governing mandates and quality methods, to design a quality system that can suit a project (pn) within the service industry. Additionally, the ontology of Figure 1 coupled with Figure 2 proposes that the QMS, once established, could illustrate a project's ability to operate in a state of 'normality' (as defined by 'c' in Figure 2). Conceptually the QMS design structure will allow an organisation to capitalise upon or support the creation of new opportunities identified in the market place and allow for new contracts to be awarded. Each element is described in Table 2.

(Figure 2)

(Table 2)

\section{Data collection}

Three service type projects, delivering different service outcomes were selected to obtain data. Qualitative hermeneutic data from telecommunications project 'Project L' in the legal sector, and quantitative empirical data from two projects in the defence industry: 'Project M' and 'Project F'. To collect data from Project L, a personal interview was conducted with the Information Technology Director focusing on the commencement and execution of a completed project. Discussion points included organisational capabilities, project planning, and modifying service design solutions upon changing customer requirements. The line of questioning was critical to ascertaining customer requirements, and to determine the amount of reliance on or collaboration with external suppliers. Summary of results are in Table 3.

\section{(Table 3)}

Two sets of data were collected from Project M. The first, a collection of 10 project improvement initiatives used to enhance the flow of a production line selected from project areas the employees deemed necessary to improve production throughput. Secondly, lag metrics were collected to identify the level of improvement the initiatives had on the production line. The data collected was used to determine the validity of improvements driven by humanistic elements or customer perceptions and what changes were made utilising differing resources in terms of product quality being an outcome driver. The manufacturing data set was collected over a 12 months period with summary of results shown in Table 4 and Figure 3. 
(Table 4)

Figure 3)

A single set of observed data was collected from Project $F$ to measure the impact change initiatives had on the project. Project F was transitioning elements of business process, database toolsets and enhancing customer relations. The degree of change is used to determine the ability to transition to a state of being flexible or adaptive and whether the amount of changes initiated where in regards to customer satisfaction or organisational need for enlightened efficiencies. The summary of results are in Table 5.

(Table 5)

Secondary sources of data collected included Australian Department of Defence contracting templates which describe the contractual arrangements between the Department of Defence and suppliers. The templates are utilised during the start- up of a project and form part of the 'customer requirements' elements in Figure 1. The data collection focused on elements of the templates that defined the quality requirements. The examination of the templates focused towards defining the types of quality objectives the customer emphasise. The results are in Table 6. A set of root cause analysis type codes were also collected to identify the type of problems that can occur within an organisation. The root cause types collected are based upon the Ishikawa model (ASQ, 2013; BRC, 2012) and are examined to determine what types of categories are used in terms of product, service, customer or organisational focus. The results are provided in Table 7.

\section{Data analysis and results}

Project L results

The information presented in Table 3 has been categorised to the quality elements defined in Table 1. The feedback identified in Table 3 indicates a convergence towards customer focus and operational management. This highlights a high degree of gathering customer requirements and off- setting with a management approach to ensure successful delivery. The establishment of assuring positive relationships with both customer and suppliers is also established. However, the focus towards customer needs became the primary focus as the suppliers capabilities were deemed important in terms of information technology rather than focusing on determining the suppliers understanding of the legal sector.

\section{Project $M$ results}

The outcomes of the initiatives outlined in Table 4 are shown in Figure 3. The data represented in Table 4 shows a diverse set of elements across Project $M$ encompassing processes and procedures, tools and improvement ideas. The impulsion for the improvement projects centred towards production efficiencies (reduction in rework, production rates and tooling enhancements). When viewed in a prioritised order, this indicates the improvements focused on problem areas, followed by strategic management objectives, humanistic challenges, finally 
focusing on project close down. Figure 3 represents the nine production line points that were subject to Project M improvement initiatives outlined in Table 4.

Common trends include:

a) Point A, C, D, E, F share the same Mean trend pattern.

b) Point B, H, I share the same Mean trend pattern.

c) Although the mean trends show a reduction in errors, the reduction rate is non-linear.

d) Point $G$ is the only Point that shows an increase in errors when changing from Part $A$ to Part B, with significant reductions in errors upon recommencement of Part A.

e) Point $\mathrm{F}$ maintained a constant error rate of 0.01 which indicates a planned and effective improvement.

f) Point I produced 10 products with zero errors which may have resulted from planned improvements or special causes.

g) In most cases, the change-over between Parts shows an increase in errors (i.e., ID 40 and 41 and also ID 53 and ID 54).

Project F results

The results detailed in Table 5 are structured in a cause and consequence (Khakzad, Khan \& Amyotte, 2012) type arrangement to establish the rationale for change, the change event and the subsequent impact the outcome of change had on Project F. The change initiatives occurred between the April 2013 and August 2013 period.

(Figure 4)

\section{Contractual content findings}

An examination of a set of defence industry contract templates (DMO, 2013a) indicated that quality aspects are focused towards warranties and defects, ISO9001 accreditation, sub contract management and addressing areas of a non- conforming quality system. A noticeable element within the contracting mechanism defined in Table 6 is the supplier is required to provide supplies (which may include goods or services) on time, on budget, to the required quality and capability. This notion can be associated with Prajogo \& Sohal (2004) assertion of performance encompassing the requirements identified in the contractual obligations. The element of warranties and defect can be associated to the statutory requirements of product and service delivery.

(Table 6.)

\section{Root Cause Analysis findings}

The fourteen root cause codes outlined in Table 7 are akin to Ishikawa (ASQ, 2013) cause and effect outliers. Common themes include product based root cause types such as design, material, equipment and manufacturing. Root cause codes that may be associated to both product and service type, including: management, personnel and human factors. The cause and effect outliers can be expanded to encompass a multitude of facets such as inputs to organisations (such as risk management systems highlighted by Andler, 2011), operating organisational departments (such as employee turnover highlighted by Ilie \& Ciocoiu, (2010)) through to product design, construction and delivery (Montgomery, 2009). 
(Table 7)

\section{Discussion}

The results from Projects L, M and F and secondary data sources provide correlation to the elements of the QMS Design model identified in Figure 1. The compelling forces that drove the projects to succeed can be identified from customer focus imperatives, although the impetus that sustained the success was born from the leadership and ingenuity of the workforce. Customer needs and the objectives that were set in order to achieve them were a common theme; such illustrations included the ability to ascertain customer requirements within Project $\mathrm{L}$ and defining the production rate target for Project M. The enhanced customer information exchange technology for Project $\mathrm{F}$ and the elements of quality management within contractual documentation also provide each project with a sense of purpose and targets to achieve.

Customer and humanistic driven innovation

The sources of innovative thinking come from multiple stakeholders (Gopalakrishnan, Kessler \& Scillitoe, 2010) that can provide projects with the means to accomplish set targets. In terms of Figure 1, an ability to innovate can be categorised as an organisational capability, however, the enabler for performing innovation may be part of the quality methods defined within the quality system. The ability to be flexible and adaptive is classed as a necessity when an organisation supplying products and services needs to accommodate changing requirements. Building flexible and responsive customer-supplier relationships can enable a supplier to collaborate with an organisation to accommodate change and capitalise upon a strengthened customer-supplier business. This can be related to Figure 2 via extending beyond the centre of normality ' $c$ ' and creating opportunities through improvements.

The improvement initiatives identified from Project $M$ are focused towards productivity efficiencies via improving processes and business practices. This is in contrast to improving efficiencies through humanistic driven ingenuity. It is noted that the areas of improvement were from the employee base; however, no mechanism existed to allow employees to improve processes that were already deemed to be effective. Although this may seem nugatory, the human compulsion of creativity would diminish if the only impulsion for change was to solve a problem rather than capitalise upon an opportunity. Rectification innovation occurred on Project $\mathrm{M}$ to move from a state of poor quality towards ' $c$ ', in the sense of enhancing manufacturing techniques such as Paint shop [03] and Jigs and Tooling [07]. Conversely, component delays [05] and document management [09] can be viewed as taking corrective action whilst suggested improvements [08] can be construed as taking preventive action, sourced from employee knowledge rather than internal audit activity. This illustrates, according to Figure 2, both rectification innovation and improvement innovation can occur in parallel, supported by top management prioritising innovation so long as not focusing solely on rectification.

Employee ingenuity and creativity requires a process and toolset to allow the transition from discussion to trial, implementation and standardisation of effective processes. A mechanism is required to allow for improvement innovation and continual improvement as identified by the PDCA cycle in Figure 2. This is provided by employee impulsion for improvement and realisation for opportunities, rather than an appraisal (such as an audit) which invokes a corrective or preventive action.

Primary performance drivers

Quality planning is an imperative providing the impetus for supplies to conform to customer requirements and institute value when focusing on return on investment (leading to profits) and opportunities rather than focusing purely on the costs the quality systems exert on an 
organisation (Freiesleben, 2004). Figure 1 identifies an association between the QMS design output (QMSpx) and 'Market opportunities or project award' by using a quality system to grow an organisation beyond ' $c$ '. However, the ability to prevent problems from reoccurrence derives from benchmarking current effective processes across industries or reviewing and analysing activities recently performed (as discussed by Melkonian \& Picq, 2011). An advantage of approaches such as pilot projects or providing proof of concept design allows an evaluation of staged chronological performance. Such an approach is highlighted from Project L and can be correlated to methods such as Plan Do Study Act (PDSA) devised by Moen \& Norman (2009). Objectives are set (plan), and carried out (do) with post-briefings conducted to summarise findings, compared to predictions (study) and finally act on the recommendations (act). The post-briefings and enactment on recommendations would allow projects to set quality measures to determine the effectiveness of being flexible and adaptive to change.

Although productivity improvements were sought and attained on Project M (reduction of errors at production point $\mathrm{F}$ in Figure 3), the improvement initiatives identified in Table 4 did not provide a linear trend towards zero errors. The techniques employed were utilised across the ten improvement initiatives. This indicates that Project $\mathrm{M}$ became flexible in order to adopt and adapt (as discussed by Ahire \& Ravichandran, 2001) improvement methods such as process mapping, value adding and waste reduction provided a common parlance such as the paint shop [03], jigs \& tooling [07] and Point G [01].

Performance drivers from Project $\mathrm{L}$ and Project $\mathrm{M}$ were driven from customer requirements but enabled by supplier capabilities and employee participation. The customer, supplier and employees were imperative stakeholders who, in association with a quality system, provide driving forces for planning and improving project performance. The change framework initiative shown in Figure 4 highlights the strategy and stakeholders as initiators for changing Project F's outcomes. The change framework initiative, modelling on the ABEF, provides the overarching instrument to enact change. The change events identified in Table 5, are centred towards customer satisfaction and project operations, which are differentiated from Project L and Project $\mathrm{M}$ in terms of investing in technology to enhance productivity.

The contractual templates do not state performance drivers as related to quality, as they only articulate warranties, defects and non- conformances. These can be classed as lag indicators as they are invoked after a non- conformity has been found. Contractual obligations (as related to Figure 1), assert an expectation for delivering on time, however, the contractual statements also factor in the reality of defective supplies and services. Performance drivers equate to defect free products and services. Conversely the contractual templates tend to focus towards the cost of poor quality as the premise of quality performance of a project, so customer dissatisfaction (due to warranty claims or defective products and services), invokes either corrective action or rectification innovation (as defined within the cost of poor quality in Figure 2).

The amount of investment, expenditure and effort in quality may be performed by both corrective and preventive action or by equally proportional rectification innovation. As defined in Table 5, Project $\mathrm{F}$ embarked on introducing new technology to remove arduous processes. By utilising corrective and preventive actions, Project F may return to 'c', undercapitalising upon growth opportunities. Conversely, by introducing new technology (via equally proportional rectification innovation), Project F may be able to use the technology in newly identified market opportunities, highlighting innovation having a high degree of impact. In both instances, the objective is to utilise either corrective and preventive action, or rectification innovation to return Project $\mathrm{F}$ to a state of normality, prior to reaching a point where an organisation is unrecoverable. The ability to enhance capability, such as establishing a corporate toolset repository in Project F (Table 5) or designing human machine interfaces in Project L (Table 3), 
may allow an organisation into a state of new growth via market opportunities or new contract awards.

\section{Learning from valued resources}

Quality constructs, such as standards, are valuable in developing quality systems. The ABEF, ISO10005, ISO9001 and AS8000 (Standards Australia, 2003, 2007, 2008, 2011) contribute important business, ethical and quality management aspects, formulating ground rules during the development phase of the project's QMS. The project's specified requirements associated with each of the standards need to be understood at the outset of the development phase. As an example, ISO9001:2008 sub-requirements 5.1a, 7.2.1c, and 7.3.2b, highlight that the applicable statutory and regulatory requirements to the project must be determined and accommodated in the scope of the project's controls - these sub-requirements can be associated with similar requirements contained in AS8000. Although organisations may have governance mandates, the reference to AS8000 ensures the QMS factors in organisational accountabilities.

Accountabilities can be construed to legislative requirements. The legal obligation (CCA, 2010) of acceptable quality needs to be considered when designing an effective and efficient QMS and perceived as a positive association. The focus towards a defect free product or service (as defined in contractual and legislative narrative) provides a project with impetus for improvement. The drive to reduce rework (as declared in Table 4 for Project $\mathrm{M}$ ) and standardising workflow (Table 5 for Project F) may be driven by customer need for defect free deliverables; with subsequent opportunities to capitalise on sustained rectification innovation and reductions in the non-conformance costs of poor quality.

An aspect that subsequently allowed the movement towards a state of normality, followed by continuous improvement or innovation, includes the change-over of products ( Part A $\rightarrow$ Part B $\rightarrow$ Part A defined in Figure 3). Project M allowed for employees to assess performance and introduce improvement methods with associated performance measures. Most production Points identified in Figure 3 demonstrates a mean reduction in errors for Part A (ID 24 to ID 39, then ID 54 to ID 60). Each of Part B shows a reduction except for Point G (showing a mean increase in errors). The ability to analyse the performance measures plays an imperative role as it will indicate the degree of change required in a project.

Focus of quality planning and return on investment

Leaders with foresight can focus ahead of customer requirements and apply predictability or estimative methods. Project L focused towards commencing the project at an opportune time. Conversely, customer satisfaction or external market factors may influence the project timeline. Figure 2 indicates that increased enhancement from an improvement event would increase ability to capitalise upon an opportunity. The types of capability to enact the enhancement may include standardisation of production processes (Project $\mathrm{F}$ and Project $\mathrm{M}$ ) and change-over processes, as well as reverse root cause analysis (such as driving out risks early from Project $\mathrm{L}$ as an imperative for project success). However, the improvements may not be realised from ‘improvement innovation' but from preventive action via appraisal methods.

Planning to mitigate problems potentially provides an intangible return on investment by reducing the likelihood of opportunity losses as highlighted from Project L. A method to enact on this may be to utilise aetiology quality tools. These include predictive root cause analysis (Huertas-Quintero, Conway, Segura-Velandia \& West, 2011), organisational health (Reason, 1995) or extensional methods such as failure mode probability and detect-ability (Spath, 2003) or failure mode and effects analysis (Kumar Sharma, Kumar \& Kumar, 2007) to provide predictability and prevention (Paparella, 2007). Each method will require selection based upon the requirements of the awarded project objectives and deliverables, focussing towards the common planning objective of mitigating or minimising problems. In relation to Figure 2, 
mitigation tools are utilised across both the poor and good quality domains. This also includes the application of quality statistical tools such as check-sheets, histograms, Pareto methods (Mach \& Guaqueta 2001; Charantimath, 2006) and affinity, matrix or arrow diagrams (Charantimath, 2006), which can be applied across both rectification and improvement events. The effort and expenditure would occur during the planning stage indirectly contributing the allowance for a project to meet delivery targets. It seems that by investing in quality planning as an initial driver, the outcome would be delivery of goods and services at the required customer negotiated expectations.

Changes in customer requirements may stem from the customers having non- conformances exacerbated, however, a supplier's QMS may be utilised to invoke rectification innovation to support solving a customer's problem. An aid in performing an analysis of customer problems is the use of root cause types as identified in Table 7. The design of the project's quality system at the start of a project, (at QMS Design Activity in Figure 1, identified as 'pn'), may be to invoke Potential Failure Mode Effects Analysis (PFMEA) or scenario planning. Brad (2008) highlights three aspects of QMS design and implementation which may be worth considering at the $p n$ stage as discussed above; these include a) the integration of business strategy into QMS design, b) the ability to reengineer process and c) how a project may be structured when performing a QMS design activity.

\section{Stakeholder collaboration}

As identified from Project L interview findings, customer requirements influenced the service type quality attributes. In addition, the focus towards aesthetics and serviceability were seen as a major factor in determining the customer requirements supporting Sower, Duffy, Kilbourne, Kohers, and Jones (2001) assertions of quality dimensions. This provides Project L the opportunity to revisit the project approach in the future (that is, installing new technologies). Within the context of contracting templates, there is no documentation in terms of the endogenous constructs such as benchmarking, innovation or training and knowledge \& information systems as defined in Table 1. The contractual elements focus on the 'cost, schedule and product' concepts. Customer requirements may be subject to change over time (due to political or economic factors), but it is an expectation that suppliers support the customer during the change. By quality system having to produce outcomes such as being customer focused and futuristic thinking (Gill 2009), a major aspect to the quality system can be to ensure that customer change is classed as an imperative. A quality system needs to have its own change management process to allow processes to be flexible and adaptable, not only for internal efficiencies, but for changing customer requirements. Customer liaison and consultation (defined in Figure 1) needs to be factored into the QMS design method.

Root cause analysis type categories are lag type measures focusing on post problem identification. There were no measures utilised that could have been deployed when performing the initial contract analysis for projects $\mathrm{M}$ and $\mathrm{F}$, such as PFMEA, which would have served as lead indicators - providing team members are experienced with similar projects. This includes determining preventive measures and associating them to risk management. This reduces the amount of corrective action and rectification innovation performed and focuses the efforts and expenditure towards improvement innovation. This supports the ability of a quality system creating a return on investment albeit indirectly (Wayhan, Khumawala \& Balderson, 2010), in which measures are developed to mitigate risks. This is in line with the characteristics of Project $\mathrm{L}$ as shown in Table 3.

This is contrary to the 'define the problem' declaration in Taguchi's first of eight stages of product development (Beckford, 2002) or DMAIC devised by Harry and Schroeder (Chiarini, 2013). The statement can be applied equally as 'define the opportunity' or 'capitalise on opportunities', promoting and encouraging the positive humanistic impulse for quality 
improvement. This would shift top management's commitments (Table 1) by focusing the quality effort and expenditure to the cost of Good Quality within Figure 2. The quality improvement may be initially in the form of preventive action leading to innovative thinking and back toward the centre of normality ' $c$ '. In summary, Table 8 highlights the important factors that need to be considered when devising a QMS for a newly awarded contract in the services industry.

(Table 8)

\section{Conclusion}

In order to devise a QMS for a services-industry contractual project, impelling factors need to be considered that stem from customer requirements and the realisation that organisations need to adapt to change. The 'QMS Design Model' identfies the imperative elements required to establish a QMS for such a project. Coupled with the 'Proposed Quality as Opportunity Model', both models highlight five key constructs that need consideration when devising a QMS for a newly awarded contractual project.

Although customer requirements are a driving factor, matching organisational capability is equally important. Combined with employee driven innovation, these provide the foundations for organisational success in terms of meeting these customer's requirements effectively and efficiently. In concert with employee ingenuity, a QMS needs to include quality methods, harnessed with tools, to solve problems, improve and innovate. Therefore, investment and expenditure toward implementing and maintaining a project's QMS must be continually employed to imbue corrective and preventive measures, rectification or even improvement-type innovation. On occasions during a project's life, added investment has to be made depending on 'decisions to recover' (from a poor state), or capitalising on an 'opportunity for growth'. To facilitate both these states, during the planning stages of a project its QMS should be focused on predictability and risk mitigation, allowing a project to commence in a state of 'normality'.

Industrial standards, such as ISO9001 and AS8000 provide a means for establishing a QMS in any form of industry and/or commerce, and certainly so within the contractual service industries. When standards are assessed collectively, they can provide an invaluable structure for a QMS, as they are based on critical elements such as; leadership, customer focus, quality and process improvement, employee training, knowledge \& information systems and stakeholder management. Whist these elements can be aligned to the five propositions in Table 7, service industry contractual projects have unique sets of customer requirements and internal organisational capabilities. But to enable a project to meet the customer's specified requirements and provide a return on investment (for customers and associated stakeholders), a QMS Design Model for service-industry contractual projects must add the additional propositions contained in Table 7 beyond those covered by the industrial standards' requirements to its QMS prospectively.

The required and selected elements must then be continually applied throughout the project's life, monitored and measured for effectiveness and efficiency, and, subsequently in retrospect, reviewed to retain the lessons learned and in doing so, enhance capability and add to the organisation's body of knowledge. Such deployed knowledge can become a sustainable competitive advantage. It can assure current customers that the organisation will be capable of successfully completing future projects and the confidence to bid on potential customer projects with the knowledge that as an organisation, they are truly capable. As Dr W. Edwards Deming, a leading founder of the modern quality movement is widely attributed as having once said: 'It is not necessary to change. Survival is not mandatory'. 


\section{References}

Ab Wahid, R.A., \& Corner, J. (2009) Critical success factors and problems in ISO 9000 maintenance, International Journal of Quality \& Reliability Management, Vol.26, Iss.9, p.881893.

Ahire, S.L., Golhar, D.Y., \& Waller M.A. (1996) Development and validation of TQM Implementation constructs, Decision Science, Vol.27, Iss.1, p.23-56.

Ahire, S.L., \& Ravichandran, T. 2001, An innovation diffusion model of TQM implementation, IEEE Transactions on Engineering Management, Vol.48, Iss.4, p.445-464.

ANAO. (2012) Developing and Managing Contracts: Getting the right outcome, achieving value for money. Canberra, Australia: Australian National Audit Office. Retrieved from http://www.anao.gov.au/Publications/Speeches/2009-2010/The-Business-of-Government---whypublic-sector-managment-must-evolve

Andler, N. (2011) Understanding Root Cause Analysis (2nd Ed.). Germany: Publicis. ASQ. Fishbone (Ishikawa) Diagram, American Society for Quality. Retrieved from http://asq.org/learn-about-quality/cause-analysis-tools/overview/fishbone.html

Beckford, J. (2002) Quality (2nd Ed.). Abingdon, UK: Routledge.

Bobrek, M. \& Sokovic, M. (2005) Implementation of APQP-concept in design of QMS. Journal of Materials Processing Technology, p.718-724.

Brad, S. (2008) Vectors of innovation to support quality initiatives in the framework of ISO 9001:2000. International Journal of Quality \& Reliability Management, Vol. 25, No. 7, p.674693.

BRC. (2012) Understanding root cause analysis. BRC Global Standards. Retrieved from http://www.brcglobalstandards.com/LinkClick.aspx?fileticket=HWVIw6b5a3s\%3d\&tabid=1070 $\&$ mid $=2529$

CCA. (2010) Competition and Consumer Act 2010. Canberra, Australia: Office of Legislative Drafting and Publishing, Attorney-General's Department.

Charantimath, P.M. (2006) Total Quality Management (3rd Ed.). India: Dorling Kindersley Pty Ltd.

Chiarini, A. (2013) Lean Organisation: from the tools or Toyota production system to Lean office. Italy: Springer-Verlag.

DMO. (2013a) Data Item Description (ZIP). Canberra, Australia: Department of Defence, Defence Materiel Organisation Contracting. Retrieved from

http://www.defence.gov.au/dmo/gc/asdefcon/asset_library/Support_DID_AL_V3.0.zip

DMO. (2013b) Data Item Description (ZIP) [DID-SSM-QP-V3.0.doc], Canberra, Australia: Department of Defence, Defence Materiel Organisation Contracting. Retrieved from http://www.defence.gov.au/dmo/gc/asdefcon/asset_library/Support_DID_AL_V3.0.zip DMO. (2013c) Part 3 - Draft statement of Work. Canberra, Australia: Department of Defence, Defence Materiel Organisation Contracting ASDEFCON (Complex Materiel). Retrieved from http://www.defence.gov.au/dmo/gc/asdefcon/complex_mat/2.1_docs/009_Part\%203\%20\%20SOW\%20.pdf

Ensor, P. (1988) The functional silo syndrome. Target. Spring 1988. p.16. retrieved from http://www.ame.org/sites/default/files/documents/88q1a3.pdf

EFQM. (2012) An Overview of the EFQM Excellence Model, Belgium: EFQM.

Freiesleben, J. (2004) On the limited value of cost of quality models. Total Quality Management \& Business Excellence, Vol.15, Iss.7, p.959-969.

Fuentes-Fuentes, M.M., Montes, F.J., \& Fernandez, L.M. M. (2006) Total quality management, strategic orientation and organisational performance: the case of Spanish companies. Total quality management \& business excellence, Vol.17, p.303-323.

Gill, J. (2009) Quality follows quality: add quality to the business and quality will multiply the profit. The TQM Journal, Vol.21, Iss.5, p.530-539. 
Gopalakrishnan, S., Kessler, E.H., \& Scillitoe, J. L. (2010) Navigating the innovation landscape: past research, present practice, and future trends. Organization Management Journal, Vol 7, p 262-277.

Green, Y.N.J., \& Weaver, P. A. (2006) A Sales Forecasting Benchmarking Model: A Qualitative Study. International Journal of Hospitality \& Tourism Administration, Vol.6, Iss.4, p.3-32. Huertas-Quintero, L.A.M., Conway, P.P., Segura-Velandia, D.M., \& West, A.A. (2011) Root cause analysis support for quality improvement in electronics manufacturing. Assembly Automation, Vol. 31, Iss 1, p. 38-46.

Ilie, G., \& Ciocoiu, C.N. (2010) Application of fishbone diagram to determine the risk of an event with multiple causes. Management Research and Practice, Vol. 2, Iss. 1, p. 1-20.

Juran, J.M., \& Blanton Godfrey, A. (1999) Juran's Quality Handbook (5th Ed.). Prentice-Hall p.3.1-3.50.

Khakzad, N., Khan, F., \& Amyotte, P. (2012) Dynamic risk analysis using bow-tie approach. Reliability Engineering and System Safety, Vol. 104, p.36-44.

Kumar Sharma, R., Kumar, D., \& Kumar, P. (2007) Modelling and analysing system failure behaviour using RCA, FMEA and NHPPP models. International Journal of Quality \& Reliability Management, Vol. 24, No. 5, p.525-546.

Mach, P., \& Guhqueta, J. (2001) Utilization of the Seven Ishikawa Tools (Old Tools) in the Six Sigma Strateg. 24th International Spring Seminar on Electronics Technology. May,2001.

Romania: Calimanesti-Caciulata.

McPhee, I. (2009) The Business of Government: why public sector management must evolve. Canberra: Australian National Audit Office. Retrieved from http://www.anao.gov.au/Publications/Speeches/2009-2010/The-Business-of-Government---whypublic-sector-managment-must-evolve

Melkonian, T., \& Picq, T. (2011) Building project capabilities in PBOs: Lessons from the French Special Forces, International Journal of Project Management, Vol.29, p.455-467.

Moen, R., \& Norman, C. (2009) Evolution of the PDCA cycle. Profound Knowledge Products Inc. Retrieved from http://pkpinc.com/files/NA01_Moen_Norman_fullpaper.pdf

Montgomery, D. (2009) Introduction to Statistical Quality Control (6th Ed.). USA: John Wiley $\&$ Sons Inc.

Neergaard, P. (2002) Configurations in quality management. Scandinavian Journal of

Management, Vol.18, Iss., p.173-195.

OECD (2004) OECD Principles of corporate governance. France: Organisation for Economic Co-operation and Development.

Paparella, S. (2007) Failure mode and effect analysis: A useful tool for risk identification and injury prevention. Journal of Emergency Nursing, Vol 33, Iss 4, p. 367-371.

Prajogo, D. L., \& Sohal A.S. (2004) The multidimensionality of TQM practices in determining quality and innovation performance - an empirical examination. Technovation, Vol.24, p.443453.

Quazi, H.A., Jemangin, J. Kit, L.W., \& Kian, C.L. (1998) Critical factors in quality management and guidelines for self-assessment: The case of Singapore. Total Quality Management, Vol. 9, Iss.1, p.35-55.

Reason, J. (1995) A systems approach to organisational error. Ergonomics, Vol 38, No. 8, p.1708-1721.

Rosenfeld, Y. (2009) Cost of quality versus cost of non-quality in construction: the crucial balance. Construction Management and Economics, Vol.27, p.107-117.

Sadikoglu, E., \& Zehir, C. (2010) Investigating the effects of innovation and employee performance on the relationship between total quality management practices and firm performance: An empirical study of Turkish firms. International Journal Production Economics, Vol.127, p.13-26.

SAI Global. (2011) The Australian Business Excellence Framework (GB 002-2011). Sydney, Australia: SAI Global. 
Sower, V., Duffy, J., Kilbourne, W., Kohers, G., \& Jones, P. (2001) The dimensions of service quality for hospitals: Development and use of the KQCAH scale. Health care Management Review, Vol 26, Iss. 2, p.47-59.

Spath, P.L. (2003) Home Study Program Using failure mode and effects analysis to improve patient safety. Association of Operating Room Nurses. AORN Journal, Vol. 78, Iss. 1, p.16-37. Standards Australia. (2003) Good governance principles. AS8000-2003. Sydney, Australia: Standards Australia International.

Standards Australia. (2003) Quality management systems-Guidelines for managing quality management in projects. ISO10006-2003. Sydney, Australia:SAI Global.

Standards Australia. (2007), Quality management systems - Guidelines for realizing financial and economic benefits, ISO10014-2007. Sydney, Australia: SAI Global.

Standards Australia. (2008) Quality Management System - Requirements, ISO9001:2008. Sydney, Australia: SAI Global.

Standards Australia. (2011) Managing for the sustained success of an organisation - A quality management approach. ISO9004:2011. Sydney, Australia: SAI Global.

Van Harten, W.H., Casparie, T.F., \& Fisscher, O.A.M. (2002) The evaluation of the introduction of a quality management system A process-oriented case study in a large rehabilitation hospital. Health Policy, Vol., Iss., p.17-37.

Wayhan, V.B., Khumawala, B.M., \& Balderson, E.L. (2010) An empirical test of Deming's chain reaction model. Total Quality Management, vol. 21, no.6, pp.761-777.

Weheba, G.S., \& Elshennawy. (2004) A revised model for the cost of quality. International Journal of Quality \& Reliability Management, Vol.21, Iss.3, p.291-308.

Wu, B., Kay, M., Looks, V. \& Bennett, M. (2000) The design of business processes within manufacturing systems management. International Journal of Production Research, Vol.38, Iss.17, p.4097-4111.

Zokaei, K., Seddon, J., \& O’Donovan, B. (2011) Systems Thinking: From Heresy to Practice, Private Sector Studies. UK: Palgrave Macmillan. 


\begin{tabular}{|l|l|}
\hline & \multicolumn{1}{|c|}{ Elements Critical to Quality Management } \\
\hline 1. & Leadership and Top Management Commitment \\
\hline 2. & Customer Focus \\
\hline 3. & Process Improvement and Operations Management \\
\hline 4. & Employee Training \\
\hline $\mathbf{5 .}$ & Knowledge and Information Systems \\
\hline 6. & Supplier Management \\
\hline
\end{tabular}

Table 1. Common Quality Elements

\begin{tabular}{|l|l|}
\hline \multicolumn{1}{|c|}{ Ontological Entity } & \multicolumn{1}{c|}{ Description } \\
\hline $\begin{array}{l}\text { Market Opportunities or } \\
\text { Project Award }\end{array}$ & $\begin{array}{l}\text { Growing the organisation in terms of new customers based upon } \\
\text { capabilities or sustaining the current customer products and } \\
\text { services through extension of contracts. }\end{array}$ \\
\hline $\begin{array}{l}\text { Organisational } \\
\text { Capabilities }\end{array}$ & $\begin{array}{l}\text { The value the organisation provides to an external customer in the } \\
\text { form of skills and knowledge, processes and information } \\
\text { technology and products. }\end{array}$ \\
\hline Customer Requirements & $\begin{array}{l}\text { The stated needs of the customer declaring quality, cost and } \\
\text { delivery requirements. }\end{array}$ \\
\hline $\begin{array}{l}\text { Recognised } \\
\text { Responsibilities }\end{array}$ & International standards and statutory requirements. \\
\hline Governance Mandates & $\begin{array}{l}\text { As defined by the corporate business policies. (AS 8000-2003) } \\
\text { This is in terms of equity, ethical business conduct, accountability, } \\
\text { commitment and transparency. }\end{array}$ \\
\hline QMS Design Activity & $\begin{array}{l}\text { The focus of the study - concentrating on the elements required } \\
\text { for a project ( } p 1, p 2, p 3 \ldots) \text { in which the QMS design activity is } \\
\text { associated. QMS } p x \text { denotes an instance of a QMS for a specific } \\
\text { project in the } p n \text { range. }\end{array}$ \\
\hline Quality Methods & $\begin{array}{l}\text { The employment of quality methods enables project to monitor, } \\
\text { measure and improve performance based upon customer } \\
\text { requirements (contractual or perceived). Quality planning may } \\
\text { determine the type of quality methods employed. }\end{array}$ \\
\hline QMS $p x$ & \begin{tabular}{l} 
The output of a QMS design activity \\
\hline
\end{tabular}
\end{tabular}

Table 2. QMS Design Model Descriptions 


\begin{tabular}{|l|l|l|}
\hline & Quality Element & Project Assertions \\
\hline $\mathbf{1}$ & $\begin{array}{l}\text { Leadership and Operations } \\
\text { Management }\end{array}$ & $\begin{array}{l}\text { Always start small (pilot projects, proof of concept). Big } \\
\text { bang approach may not be the best strategy. Deploy the } \\
\text { solution in stages. }\end{array}$ \\
\hline $\mathbf{2}$ & Customer Focus & $\begin{array}{l}\text { Drive out risks early - capitalise on experience from } \\
\text { previous projects to mitigate risks. }\end{array}$ \\
\hline $\mathbf{3}$ & Operations Management & $\begin{array}{l}\text { Determine the most suitable opportunity for commencing a } \\
\text { project (select the optimal point in time for change - for } \\
\text { example: office relocation). }\end{array}$ \\
\hline $\mathbf{4}$ & Customer Focus & $\begin{array}{l}\text { Declare what is needed from both the end-user and supplier } \\
\text { perspectives as this can establish a positive working } \\
\text { relationship and allow all parties to focus on the most } \\
\text { effective solutions. }\end{array}$ \\
\hline $\mathbf{5}$ & Customer Focus & $\begin{array}{l}\text { Mechanisms such as surveys are of value. Customers may } \\
\text { state 'bells-and-whistles' functionality, but over time factors } \\
\text { such as reliability and serviceability become paramount. } \\
\text { Examine human-machine interfaces. This provides a design } \\
\text { that will allow the technology to suit workflow operations } \\
\text { (end-user needs). }\end{array}$ \\
\hline $\mathbf{6}$ & $\begin{array}{l}\text { Supply Capability } \\
\text { Management }\end{array}$ & $\begin{array}{l}\text { Having sub-contractors that understand the legal system is } \\
\text { advantageous, however not the primary driver for selection. } \\
\text { Sun-contractors provide advice on business solutions using } \\
\text { their own internal business processes. }\end{array}$ \\
\hline
\end{tabular}

Table 3. Project L - Discussion Results

\begin{tabular}{|l|l|l|}
\hline ID & Improvement Project & Description \\
\hline $\mathbf{0 1}$ & Point G Enhancements & $\begin{array}{l}\text { Determine the throughput time for test and validation of } \\
\text { manufactured products. }\end{array}$ \\
\hline $\mathbf{0 2}$ & $\begin{array}{l}\text { Process Sheet } \\
\text { Consolidation }\end{array}$ & Consolidate the Process Sheets for the production Point stages. \\
\hline $\mathbf{0 3}$ & Paint Shop Enhancements & $\begin{array}{l}\text { Re-engineer paint shop processes to accommodate the 1.5 } \\
\text { production rate per week. }\end{array}$ \\
\hline $\mathbf{0 4}$ & Productivity Efficiency & $\begin{array}{l}\text { In contrast with the paint shop, ramp-up the production rate to } \\
1.5 \text { products per week. }\end{array}$ \\
\hline $\mathbf{0 5}$ & Component Delays & $\begin{array}{l}\text { How to reduce delays of ordered parts that are destined for the } \\
\text { production line. }\end{array}$ \\
\hline $\mathbf{0 6}$ & Re-work & $\begin{array}{l}\text { How to reduce re-work on the project by 10\%. Proposed } \\
\text { changes included focus on workmanship and standardisation of } \\
\text { in-process manufacturing worksheets. }\end{array}$ \\
\hline $\mathbf{0 7}$ & Jigs and Tooling & $\begin{array}{l}\text { Establish a system of utilising jigs and tooling during pre- } \\
\text { manufacturing. }\end{array}$ \\
\hline $\mathbf{0 8}$ & Suggested Improvements & $\begin{array}{l}\text { System to capture the ideas and thoughts of employees to } \\
\text { improve work practices. }\end{array}$ \\
\hline $\mathbf{0 9}$ & Document Management & $\begin{array}{l}\text { Part of the Project closure plan (Project document management } \\
\text { encompassing engineering, configuration, commercial, quality } \\
\text { and production records. This affected procedures, production } \\
\text { drawings and in-process production records, test records, stock } \\
\text { control records). }\end{array}$ \\
\hline $\mathbf{1 0}$ & Knowledge Management & $\begin{array}{l}\text { Lessons learnt and knowledge management for the project. } \\
\text { Employee training in Quality and Lean methodologies such as } \\
\text { value stream mapping, value adding, and waste elimination. }\end{array}$ \\
\hline
\end{tabular}

Table 4. Project M Improvement Initiatives 


\begin{tabular}{|c|c|c|}
\hline Change Event & Rationale (Cause) & Outcome and Impact (Consequence) \\
\hline $\begin{array}{l}\text { Established } \\
\text { Repository } \\
\text { (Information } \\
\text { System) }\end{array}$ & $\begin{array}{l}\text { Migrate to a corporate toolset } \\
\text { which is reliable and } \\
\text { standardised. }\end{array}$ & $\begin{array}{l}\text { Some degree of impact. } \\
\text { - The ability to assign accountable } \\
\text { resource to research toolset capability } \\
\text { was not performed effectively. }\end{array}$ \\
\hline $\begin{array}{l}\text { Improved Customer } \\
\text { Information } \\
\text { exchange technology } \\
\text { (Customer Focus) }\end{array}$ & $\begin{array}{l}\text { Improve working } \\
\text { relationship with customer } \\
\text { base: } \\
\text { - Immediate customer } \\
\text { - End-user customers }\end{array}$ & $\begin{array}{l}\text { High degree of impact. } \\
\text { - Allow customer requirements to be } \\
\text { discussed and clarified. } \\
\text { Workforce collaboration between } \\
\text { customer and supplier increased. } \\
\text { Enhance the product delivery method. }\end{array}$ \\
\hline $\begin{array}{l}\text { Standardise } \\
\text { Workflow } \\
\text { (Operations } \\
\text { Management) }\end{array}$ & $\begin{array}{l}\text { Remove non value- adding } \\
\text { process steps. Stabilise } \\
\text { processing times and remove } \\
\text { opportunities for defects. }\end{array}$ & $\begin{array}{l}\text { Some degree of impact. } \\
\text { - The bottlenecks and areas of non value- } \\
\text { adding are recognised. }\end{array}$ \\
\hline $\begin{array}{l}\text { Introduce New } \\
\text { Technology } \\
\text { (Information } \\
\text { Systems) }\end{array}$ & $\begin{array}{l}\text { Remove arduous processes. } \\
\text { Allow efficiencies to be } \\
\text { realised via hands-on access } \\
\text { to information on an as- } \\
\text { required basis. }\end{array}$ & $\begin{array}{l}\text { High degree of impact. } \\
\text { - Research information technologies. } \\
\text { Purpose was to enhance workflow and } \\
\text { provide clarity and accuracy of } \\
\text { technical data. }\end{array}$ \\
\hline $\begin{array}{l}\text { Development of an } \\
\text { overarching change } \\
\text { framework }\end{array}$ & $\begin{array}{l}\text { A mechanism to manage } \\
\text { changes to Project } F \\
\text { encompassing: } \\
\text { - Rectification innovation } \\
\text { - Improvement } \\
\quad \text { innovation }\end{array}$ & $\begin{array}{l}\text { Medium degree of impact. } \\
\text { The change framework was based upon the } \\
\text { ABEF. The change framework was } \\
\text { established to instigate improvements from } \\
\text { within Project F. }\end{array}$ \\
\hline
\end{tabular}

Table 5. Project F Results

\begin{tabular}{|l|l|}
\hline Conditions of & $\begin{array}{l}\text { "The objectives of the parties in entering into this Contract are: a) to ensure that } \\
\text { the Contractor delivers the Supplies on time, on budget, to the required safety, } \\
\text { quality and capability, in accordance with the Contract" (DMO, 2013b). }\end{array}$ \\
\hline $\begin{array}{l}\text { Warranties } \\
\text { and Defects }\end{array}$ & $\begin{array}{l}\text { "The Contractor shall remedy by repair, replacement or modification and other } \\
\text { Supplies which are affected by the corrective actions taken by the Contractor" } \\
\text { (DMO, 2013b). }\end{array}$ \\
\hline $\begin{array}{l}\text { ISO9001 } \\
\text { Certification }\end{array}$ & $\begin{array}{l}\text { "During progress of work under the Contract, the Commonwealth may at its } \\
\text { discretion perform Audit and Surveillance activities in relation to the work } \\
\text { performed, including any of the following: a) System Audit; b) Process Audit; or } \\
\text { c) Product Audit" (DMO, 2013c). }\end{array}$ \\
\hline $\begin{array}{l}\text { Subcontract } \\
\text { Management }\end{array}$ & $\begin{array}{l}\text { "The Contractor shall ensure that all work performed under a Subcontract meets } \\
\text { the requirements of the QMS to be applied by the Contractor" (DMO, 2013c). }\end{array}$ \\
\hline $\begin{array}{l}\text { Non- } \\
\text { Conforming } \\
\text { Products }\end{array}$ & $\begin{array}{l}\text { "The Contractor shall take whatever action is necessary to correct a legitimate } \\
\text { quality system/process/product non-conformance" (DMO, 2013c). }\end{array}$ \\
\hline
\end{tabular}

Table 6. Contractual Declarations 


\begin{tabular}{|c|c|c|}
\hline & Type & Focus \\
\hline 1 & Design & $\begin{array}{l}\text { 1. Design baseline discrepancies } \\
\text { 2. Design changes } \\
\text { 3. Data management } \\
\text { 4. Requirements analysis }\end{array}$ \\
\hline 2 & Documentation & $\begin{array}{l}\text { 1. Maintaining records } \\
\text { 2. Configuration management }\end{array}$ \\
\hline 3 & Equipment & $\begin{array}{l}\text { 1. Calibration } \\
\text { 2. Damaged equipment }\end{array}$ \\
\hline 4 & Management & $\begin{array}{l}\text { 1. Performing reviews } \\
\text { 2. Contract management, planning }\end{array}$ \\
\hline 5 & Material & $\begin{array}{l}\text { 1. Correct type of material supplied } \\
\text { 2. Shelf life control } \\
\text { 3. Aesthetics }\end{array}$ \\
\hline 6 & Personnel & $\begin{array}{ll}\text { 1. } & \text { Workmanship } \\
\text { 2. } & \text { Training } \\
\text { 3. } & \text { Following instructions }\end{array}$ \\
\hline 7 & Human Factors & $\begin{array}{l}\text { 1. Communication and teamwork } \\
\text { 2. Fatigue and stress } \\
\text { 3. Distraction and violations } \\
\text { 4. Knowledge }\end{array}$ \\
\hline 8 & $\begin{array}{l}\text { Process and } \\
\text { Procedures }\end{array}$ & $\begin{array}{l}\text { 1. Documented } \\
\text { 2. Adequacy }\end{array}$ \\
\hline 9 & Machine & $\begin{array}{l}\text { 1. Wear and tear } \\
\text { 2. Damage }\end{array}$ \\
\hline 10 & External & $\begin{array}{l}\text { 1. Delivery efficiencies (Time) } \\
\text { 2. Correct parts supplied }\end{array}$ \\
\hline 11 & Health and Safety & $\begin{array}{ll}\text { 1. } & \text { Accident } \\
\text { 2. } & \text { Hazardous substances control }\end{array}$ \\
\hline 12 & Supplier & $\begin{array}{l}\text { 1. Correct parts supplied } \\
\text { 2. Contract effective }\end{array}$ \\
\hline 13 & Manufacturing & $\begin{array}{l}\text { 1. } \text { Correct supplies utilised } \\
\text { 2. Part fit-for-use } \\
\text { 3. Workmanship }\end{array}$ \\
\hline 14 & Unknown & $\begin{array}{l}\text { 1. Records and investigation } \\
\text { 2. Resource available } \\
\text { 3. Last time of occurrence }\end{array}$ \\
\hline
\end{tabular}

Table 7. Root Cause Types (Project M and Project F) 


\begin{tabular}{|c|c|c|}
\hline & Propositions & Results \\
\hline 1 & $\begin{array}{l}\text { Customer and } \\
\text { humanistic driven } \\
\text { innovation }\end{array}$ & $\begin{array}{l}\text { - The ability to be flexible and adaptive may be classed as a } \\
\text { necessity to accommodate customer and supplier requirements. } \\
\text { Employee based improvements is an imperative to allow for } \\
\text { sustained creativity. } \\
\text { - The Quality systems needs to employ methods and tools for } \\
\text { rectification, improvement, correction and prevention. }\end{array}$ \\
\hline 2 & $\begin{array}{l}\text { Primary performance } \\
\text { drivers }\end{array}$ & $\begin{array}{l}\text { - } \quad \text { Driven from the customer needs. } \\
\text { - Customer requirements are for defect free deliverables. } \\
\text { - Utilisation of an excellence framework can provide a model for } \\
\text { sustaining improvements across projects. }\end{array}$ \\
\hline 3 & $\begin{array}{l}\text { Learning from } \\
\text { valued resources }\end{array}$ & $\begin{array}{l}\text { - } \\
\text { - } \quad \text { Utilising experienced staff. } \\
\text { - Statutory and regulatory requirements as well as industry } \\
\text { standards and good practice (per McPhee 2009). } \\
\text { - Leadership foresight and planning capabilities. } \\
\text { - Anticipating (often unstated) customer requirements/quality } \\
\text { improvements. }\end{array}$ \\
\hline 4 & $\begin{array}{l}\text { Focus on quality } \\
\text { planning and return } \\
\text { on investment }\end{array}$ & $\begin{array}{l}\text { Utilise methods that focus on mitigation, probability, } \\
\text { predictability, detection and prevention. } \\
\text { Never lose sight of the potential for follow-on work or awarded } \\
\text { a new project. } \\
\text { Factor in the QMS being designed to support seeking new } \\
\text { market opportunities. }\end{array}$ \\
\hline 5 & $\begin{array}{l}\text { Stakeholder } \\
\text { collaboration }\end{array}$ & $\begin{array}{l}\text { - Establish a quality process that enables change management to } \\
\text { compliment and support flexibility and adaptability to changing } \\
\text { customer requirements. } \\
\text { - Customer and supplier domain knowledge. }\end{array}$ \\
\hline
\end{tabular}

Table 8. Summarisation of Quality Management System Design Factors

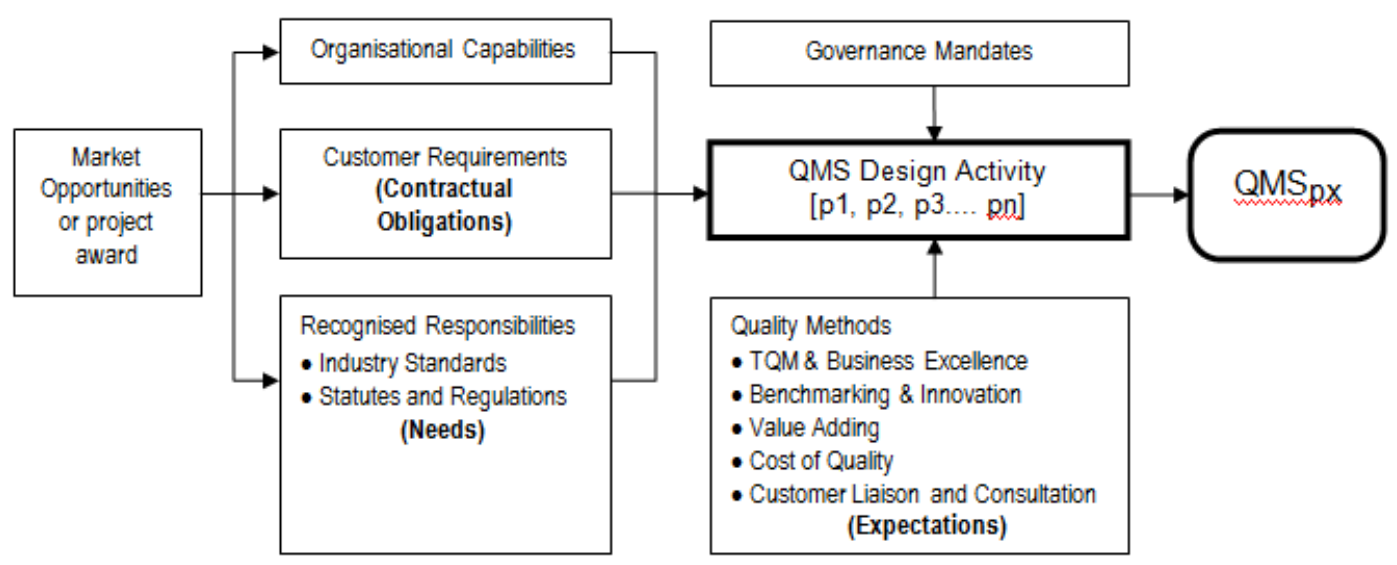

Figure 1. QMS Design Model 


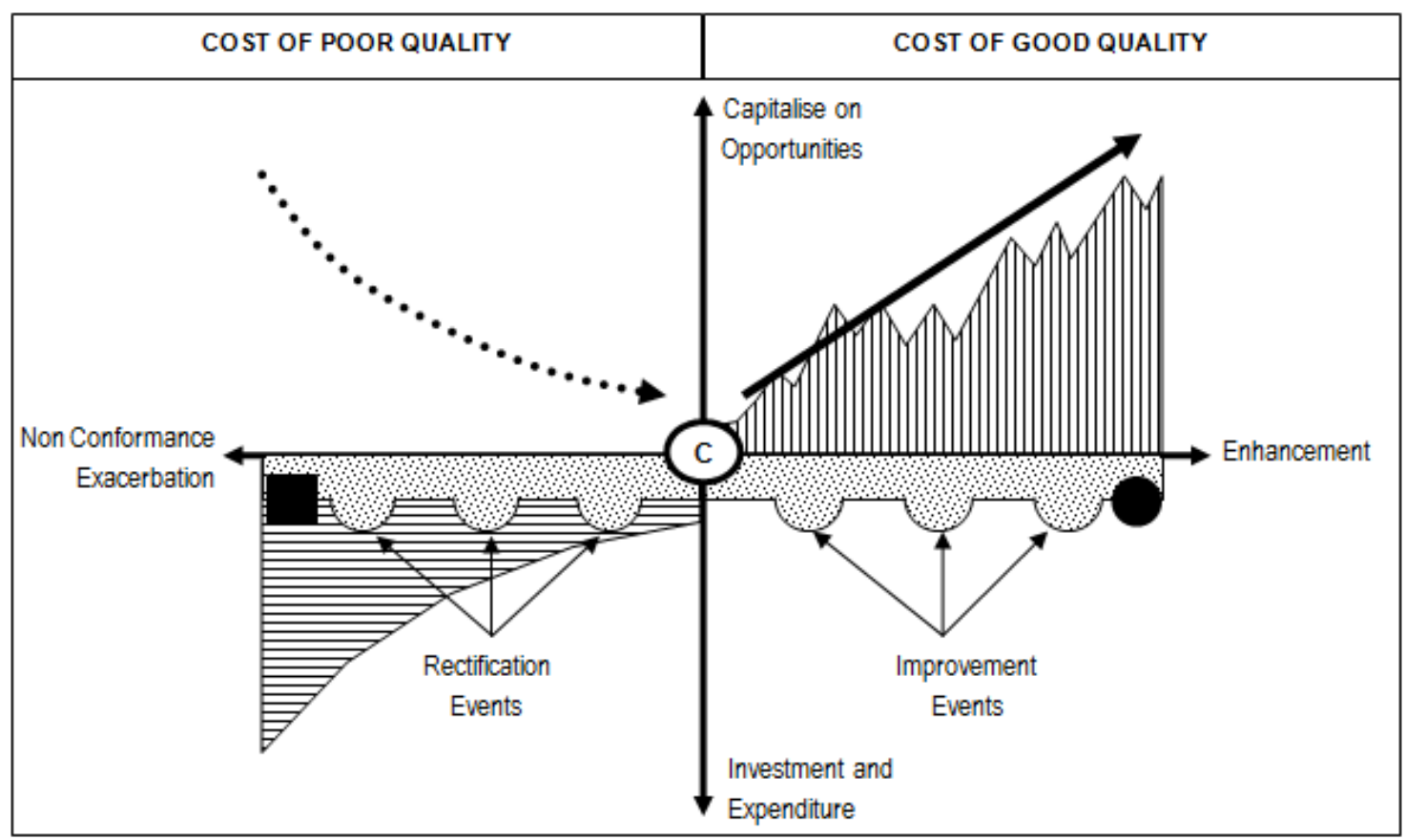

|.|W||| Continual Improvement staircase (PDCA cycle - good quality)

W. Effortexpended for Quality (financial, effort, knowledge)

Cost of non conformance (poor quality, opportunity loss)

$\cdots$ Rectification Innovation (invoking innovation to solve a problem)

$\rightarrow$ Improvement Innovation (enhancing a capability)

Decision to innovate to recover the business system

- Opportunity for growth and capitalise upon the business system

C Centre of normality - zero or few non conformances and zero or few improvements

\begin{tabular}{|l|l|}
\hline $\begin{array}{l}\text { Rectification } \\
\text { Event }\end{array}$ & $\begin{array}{l}\text { An activity utilising quality methods, innovative initiatives, organisational resources and } \\
\text { capabilities to solve a given problem. This could be in the form of poor process, workforce } \\
\text { training or product or service delivery non conformances. }\end{array}$ \\
\hline $\begin{array}{l}\text { Improvement } \\
\text { Event }\end{array}$ & $\begin{array}{l}\text { An activity utilising quality methods, resources and capabilities to enhance a current capability } \\
\text { or introduce a new capability that will provide the organisation to capitalise upon opportunities } \\
\text { such as increased profit or invest into new customer markets. }\end{array}$ \\
\hline
\end{tabular}

Figure 2: Proposed Quality as Opportunity Model 


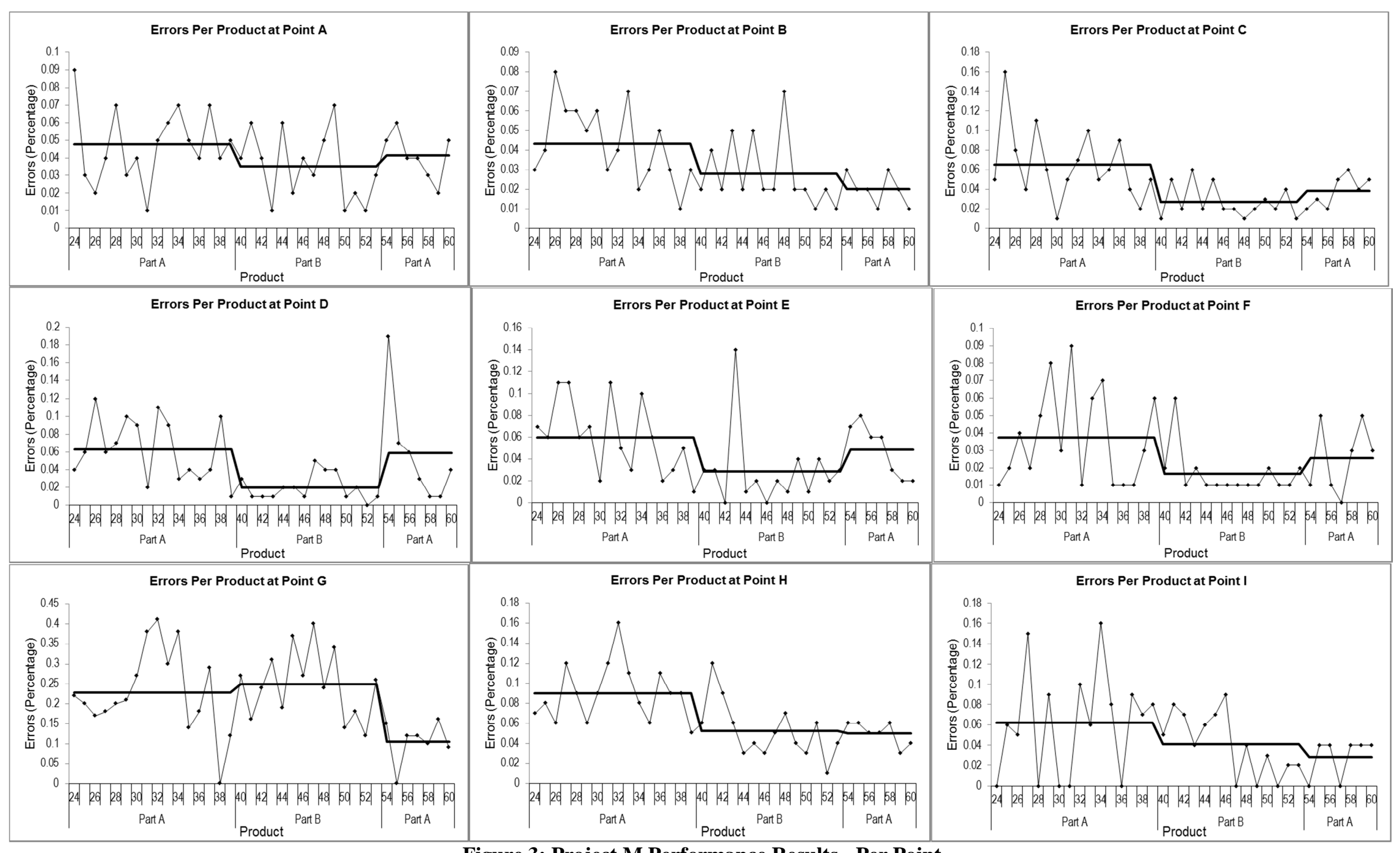

Figure 3: Project M Performance Results - Per Point 


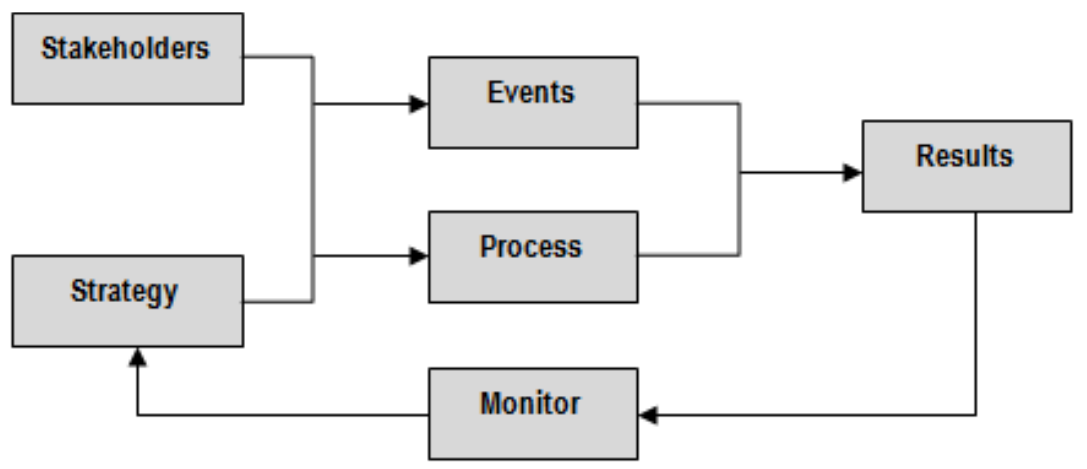

Figure 4: Project F Change Framework Initiative 